\title{
IMMUNOLOGICAL AND CLINICAL STUDIES ON VACCINATED DOGS WITH THE LIVE ATTENUATED CANINE ADENO-1 VIRUS VACCINE
}

\author{
EDREIS, S.M. ${ }^{1}$; A.M. ALBEHWAR ${ }^{1}$; N.M. SOBHY ${ }^{2}$ and M.A. ZAGHLOOL ${ }^{3}$ \\ 1. Veterinary Serum and Vaccine Research Institute, Abbasia Cairo \\ 2. Faculty of Veterinary Medicine, Zagazig University \\ 3. Central Laboratory for Evaluation of Veterinary Biologics, Abbasia Cairo
}

(Manuscript received 12 September 2017)

\begin{abstract}
$\mathrm{T}$ he immunogenicity and clinical safety of a local live attenuated canine adenovirus- 1 vaccine (CAV-1) were evaluated in experimentally vaccinated native breed 3-4 months puppies. All vaccinated puppies did not show any abnormalities post vaccination. Studying the blood picture revealed no changes in RBCs and hemoglobin values while there was an increase in the levels of total WBCs count, lymphocyte \%, total serum protein and serum globulin. Liver and kidney function tests results were found to be within the normal values. These findings insure the vaccine safety. On the other side, serum neutralization test was carried out on sera of vaccinated puppies and showed that these animals exhibited good levels of specific CAV-1 serum neutralizing antibodies able to protect them against virus infection. So, it could be said that the local CAV-1 vaccine is immunogenic vaccine suitable for dog protection against infectious canine hepatitis.
\end{abstract}

\section{INTRODUCTION}

Canine adeno virus-1 is a member of the family Adenoviridae which is classified into five genera: Mastadenovirus, Aviadenovirus, Atadenovirus, Siadenovirus and Ichtadenovirus (Harrach et al., 2011). Adenoviruses are non-enveloped, icosahedral viruses with diameter ranges from 70 to $100 \mathrm{~nm}$. Their double-stranded DNA genomes are linear, non-segmented, ranging in size from 26 to $48 \mathrm{~kb}$, and typically contain between 22 and 40 genes (Davison et al., 2003).

Infectious canine hepatitis (ICH), is an adenoviral disease affecting young Canidae and Uridae, and characterized clinically by inapparent to rapidly fatal disease (Whetstone et al., 1988 and Greene, 1990) caused by Canine adenovirus-1 (CAV-1) which affects both endothelial and hepatic cells. In addition to acute hepatocellular necrosis, acute severe hemorrhages are seen on serosal surfaces, within lymph nodes and the liver, and rarely in the brain (Greene, 1990 and Kelly, 1993). Physical examination in acute ICH often reveals fever and increased respiration rates, lymphadenopathy and a hemorrhagic diathesis that ranges from petechiation to fulminant bleeding. 
Acute hepatitis, accompanied by hemorrhages and disseminated intravascular coagulation, are the most common signs. In convalescent stage in some cases, an ocular reaction that include antigen-antibody interactions result in corneal edema and anterior uveitis (characteristic "blue eye") and multifocal interstitial nephritis.

Canine adenovirus-1 transmission occurs through the oronasal route and excreted in the urine of carrier animals for up to 6 months. Vaccination has successfully reduced the spread of ICH in recent years (Kelly, 1993). Another route of exposure could be through contamination of the puppies' environment. Exposure accompanied by lack of maternal immunity may make the puppies predisposed to be diseased.

Immunity after natural infection with CAV-1 is probably life long. Effective vaccines have been available and widely used as part of core vaccine programs for dogs for many years. Immunity after vaccination with attenuated live vaccines lasts Öwere associated with the development of corneal edema and glomerulonephritis in a small percentage of immunized dogs. Replacement of attenuated live CAV-1 with CAV2 is made after 1980 and eliminated this side effect (Bass et al., 1982). Carmichael (1999) reported that modified live vaccines induced specific antibodies that persisted for as long as 14 years leading to full protection against ICH infection. After application of widespread vaccination, only sporadic cases were reported, as usually occurring in unvaccinated dogs. Modified live CAV-1 vaccines are successfully reduced the circulation of the virus in canine populations (Twark and Dodds, 2000; Coyne et al., 2001; Soma, 2002; Khodeir et al., 2003; Böhm et al., 2004 and Mohammadi et al., 2011).

It is well known that successful vaccination is that one which has not any side effect, the thing which may be apparent (showing no clinical signs), but the body functions should be investigated where they may be affected with either live or chemically inactivated vaccines.

The present work was designed to investigate the effect of the live attenuated canine adeno- 1 vaccine on some body organs functions and blood composition of vaccinated puppies in addition to follow up the levels of induced immunity.

\section{MATERIALS AND METHODS}

\section{1-Animals:}

Eight native breed puppies of 3-4 months of age were subjected for experimental vaccination with the local canine hepatitis virus vaccine (canine adeno1 virus). They were proved to be free from canine adeno-1virus antibodies. The 
puppies were divided into 2 groups. The first group (5 puppies) was vaccinated with a dose of $10^{3}$ TCID $50 / a n i m a l$ inoculated subcutaneously, while the second group (3 puppies) was kept without vaccination as a test control. All animals were housed in separate kennels under hygienic measures receiving balanced diet and adequate water. Blood and serum samples were collected from all animals with a week intervals post vaccination up to 4 weeks then with a month intervals up to 3 months. Serum samples were subjected to investigation of the induced antibody levels and evaluation of kidney and liver functions.

\section{2-Infectious canine hepatitis vaccine:}

Live attenuated canine adeno- 1 vaccine was supplied by the Department of Pet Animal Vaccine Research (PAVR), Veterinary Serum and Vaccine Research Institute (VSVRI) Abbasia, Cairo, Egypt. This live virus vaccine was used for vaccination of experimental puppies and estimation of serum neutralizing antibodies induced in vaccinated animals through application of SNT.

\section{3-Cell culture:}

African green monkey kidney cell line (Vero) established by Yasumara and Kawatika (1963) was supplied by the Department of Pet Animal Vaccine Research, (VSVRI) and used for vaccine preparation and titration of CAV-1 in vaccinated animals using SNT.

\section{4-Serum Neutralization test (SNT):}

SNT was carried out using the microtiter technique according to Bass et al. (1982) to determine CAV-1 antibody levels and immune status in examined dogs while the serum neutralizing antibody titer was expressed as the reciprocal of the final serum dilution which neutralized and inhibited the cytopathic effect (CPE) of 100 TCID $_{50}$ of ICH virus according to Singh et al. (1967).

\section{5-Blood examination:}

According to Robert and Keith (1986) total red blood cells (RBCs) count; total white blood cells (WBCs) count; lymphocyte \% and hemoglobin $(\mathrm{Hb})$ value were estimated in blood samples obtained from all experimental puppies post experimental vaccination with $C A V-1$ vaccine.

\section{6-Biochemical kits:}

Kits used for evaluation of liver and kidney function tests were supplied by Biomerieux Laboratory Reagents and Products, Marcyl Etoil, France. 


\section{7-Serum biochemical analysis:}

\section{1-Liver function tests:}

Total Protein, Albumin, Globulin, Albumin/ Globulin Ratio, Total Bilirubin, serum alanine aminotransferase (ALT) \{serum glutamic pyruvic transaminase "SGPT"\}, Serum aspartate aminotransferase (AST) \{serum glutamic oxaloacetic transaminase "SGOT" $\}$ and Alkaline Phosphatase, were evaluated using specific kits according to the methods described by Reitman and Frankel (1957).

\section{2-Kidney function tests:}

Serum urea nitrogen was determined spectrophotometerically according to Patton and Croush (1977) while serum creatinine was determined according to Henry (1974).

\section{RESULTS AND DISCUSSION}

The obtained results tabulated in table (1) showed that total RBCs count and $\mathrm{Hb}$ values in vaccinated puppies were within the normal levels. On the other side, total WBCs count and lymphocyte \% showed increased values in vaccinated puppies by the first week post vaccination to be $18.72 \times 10^{3} / \mu$ land $92 \%$ respectively while these values were $12 \times 10^{3} / \mu \mathrm{l}$ and $25 \%$ in non-vaccinated control puppies. Such elevated values in vaccinated animals could be attributed to the inoculation of the live virus vaccine reflecting the animal body response where these parameters returned again to their normal levels by the second week post vaccination $\left(16.6 \times 10^{3} / \mu l\right.$ and $30 \%$ respectively). These findings came in agreement with those of Sharma et al. (1973); Taha et al. (1984); Hanan (1998) and Mouaz et al. (1998) who attributed the increase in lymphocyte $\%$ to their sharing in the production of antibodies in vaccinated animals with live attenuated PPR vaccine.

Table (2) demonstrates an increase in the values of total serum protein and serum globulin recording their peaks $\left(7.11\right.$ and $3.31 \mathrm{~g} / \mathrm{dl}$ respectively) by the $4^{\text {th }}$ week post vaccination and according to this result the $A / G$ ratio recorded nearly its lowest value (1.14) on the same week. The increase in serum globulin is attributed to the formation of antibodies which mainly formed of IgG as concluded by Taha et al. (1984); Kataria and Sharma (1993) and Soliman et al. (1996).

On the other side, evaluation of liver functions including ALT, AST and ALP revealed slight changes although these changes were within the normal levels.

Regarding the following up of kidney functions in experimental puppies, it was found that the vaccine did not affect the levels of serum creatinine and urea allover the experiment period as they were remained within the normal values confirming the safety of the used vaccine in agreement with what reported by Khodeir 
et al. (2003) and Emam (2008). Also similar normal liver and kidney functions parameters in healthy dogs were recorded by Emam et al. (2013).

Table (4) showed gradual increase in the levels of CAV-1 serum neutralizing antibodies in vaccinated puppies in agreement with the findings of Chappuis (1980); Khodeir et al. (2003) and Emam (2008) who recorded similar findings using live CAV-1 attenuated vaccine.

According to the obtained results, it could be concluded that the live attenuated CAV-1 vaccine (prepared from the local strain) is safe inducing no abnormal clinical or biochemical changes in vaccinated puppies and immunogenic inducing good levels of specific serum neutralizing antibodies beginning from the third week post vaccination, reaching its maximum level by the fourth week post vaccination, so it is suitable for protection of puppies against infectious canine hepatitis although there are some workers showed that similar vaccines could cause some post vaccination undesirable signs as blue eye. Such finding could be attributed to the viral strain or the degree of virus attenuation. So the prepared vaccine could be used safely and efficiently for controling the disease Table 1. Blood picture of vaccinated and non- vaccinated puppies

\begin{tabular}{|c|c|c|c|c|c|c|}
\hline \multirow[t]{2}{*}{ Blood parameters } & \multicolumn{4}{|c|}{ parameters values in vaccinated puppies/WPV* } & \multirow[b]{2}{*}{ Control } & \multirow{2}{*}{$\begin{array}{c}\text { Standard } \\
\text { values }\end{array}$} \\
\hline & 1WPV & 2WPV & 3WPV & 4WPV & & \\
\hline $\begin{array}{l}\text { RBCs count } \\
\qquad\left(\mathrm{n} \times 10^{6} / \mu \mathrm{l}\right)\end{array}$ & 5.32 & 5.64 & 5.40 & 5.30 & 5.7 & $5.5-8.5$ \\
\hline $\begin{array}{l}\text { Total WBCs count } \\
\left(\mathrm{n} \times 10^{3} / \mu \mathrm{l}\right)\end{array}$ & 18.72 & 17.68 & 17.50 & 16.6 & 12 & $6-17$ \\
\hline (Lymphocyte) LYM\% & 92 & 87 & 70 & 30 & 25 & $12-30$ \\
\hline $\mathrm{Hb} \mathrm{g/dl}$ & 11 & 10.5 & 11.2 & 11.5 & 12 & $12-18$ \\
\hline
\end{tabular}

WPV $=$ Weeks Post Vaccination

Table 2. Liver function parameters of vaccinated and non - vaccinated puppies

\begin{tabular}{|c|c|c|c|c|c|c|}
\hline \multirow{2}{*}{ Tested parameters } & \multicolumn{2}{|c|}{ Blood values in vaccinated puppies/WPV* } & \multicolumn{2}{c|}{ Control } & $\begin{array}{c}\text { Standard } \\
\text { values }\end{array}$ \\
\cline { 2 - 6 } & 1WPV & 2WPV & 3WPV & 4WPV & 6.13 & $5-7.4$ \\
\hline Total protein (g/dl) & 5.99 & 6.5 & 6.12 & 7.11 & 6.13 & $2.7-4.4$ \\
\hline Albumin (g/dl) & 4.25 & 3.57 & 3.12 & 3.8 & 3.19 & $1.6-3.6$ \\
\hline Globulin (g/dl) & 1.74 & 2.93 & 3.00 & 3.31 & 2.94 & $0.8-2.0$ \\
\hline A/G ratio & 2.44 & 1.21 & 1.04 & 1.14 & 1.08 & $0.1-0.3$ \\
\hline Total bilirubin (g/dl) & 0.15 & 0.18 & 0.12 & 0.15 & 0.61 & $5-107$ \\
\hline ALT (U/L) & 25.5 & 29.00 & 42.5 & 38.14 & 30.09 & $5-55$ \\
\hline AST (U/L) & 40.40 & 20.06 & 39.10 & 45.00 & 24.15 & 10 \\
\hline ALP (U/L) & 140 & 140.9 & 139.17 & 113.15 & 102.9 & $10-150$ \\
\hline
\end{tabular}

$* \mathrm{WPV}=$ Weeks Post Vaccination

Table 3. Kidney function parameters in vaccinated and non-vaccinated puppies

\begin{tabular}{|c|c|c|c|c|c|c|}
\hline \multirow{2}{*}{ Tested parameters } & \multicolumn{3}{|c|}{ Blood values in vaccinated puppies/WPV } & \multirow{2}{*}{$\begin{array}{c}\text { Standard } \\
\text { values }\end{array}$} \\
\cline { 2 - 6 } & 1WPV & 2WPV & 3WPV & 4 WPV & Control & 0.46 \\
\hline Creatinine Mg/dl & 0.58 & 0.61 & 0.68 & 0.73 & 0.46 & 0.1 .6 \\
\hline Urea Mg/dl & 18.29 & 24.29 & 16.74 & 22.78 & 27.16 & $8.7-30.5$ \\
\hline
\end{tabular}


Table 4. Infectious canine hepatitis serum neutralizing antibody titers

\begin{tabular}{|c|c|c|c|c|c|c|c|}
\hline \multicolumn{6}{|c|}{ Canine hepatitis serum neutralizing antibody titer*/WPV* in Vaccinated puppies } \\
\hline $\begin{array}{c}\text { Animal } \\
\text { number }\end{array}$ & 1WPV & 2WPV & 3WPV & 4WPV & 8 WPV & 12 WPV & Control \\
\hline 1 & 8 & 16 & 32 & 64 & 64 & 64 & 0 \\
\hline 2 & 4 & 8 & 32 & 32 & 64 & 64 & 0 \\
\hline 3 & 8 & 16 & 32 & 64 & 64 & 64 & 0 \\
\hline 4 & 8 & 16 & 32 & 64 & 64 & 64 & 0 \\
\hline 5 & 4 & 8 & 16 & 32 & 32 & 32 & 0 \\
\hline Mean & 6.4 & 12.8 & 28.8 & 51.2 & 57.6 & 57.6 & 0 \\
\hline
\end{tabular}

*Serum neutralizing antibody titer $=$ the reciprocal of the final serum dilution which neutralized and inhibited the CPE of 100 TCID $_{50}$ of CAV-1

** WPV $=$ Weeks Post Vaccination

\section{REFERENCES}

1. Bass,E.P.; Gill, M.A. and Beckenhaur, W.H. 1982. Development of a modified live canine origin parvo virus vaccine. J.A.V.M.A., 181 (9): 909-913.

2. Böhm, M., Thompson, H. and Weir, A. 2004. Serum antibody titers to canine parvovirus, adenovirus and distemper virus in dogs in the UK which had not been vaccinated for at least three years. Vet. Rec., 154: 457-463.

3. Carmichael LE. 1999. Canine viral vaccines at a turning point - a personal perspective. Advances in Veterinary Medicine, 41: 289-307.

4. Chappuis, G. 1980. Immunization of dogs against viral hepatitis with canine adenovirus type-2. Recueil-de-Med-Vet., 156 (2): 109-114

5. Coyne, M.J., Burr, J.H. and Yule, T.D. 2001. Duration of immunity in dogs after vaccination or naturally acquired infection. Vet. Rec., 149:509-515.

6. Davison, A. J.; Benko,M. and Harrach, B. 2003. Genetic content and evolution of adenoviruses. J. Gen. Virol., 84 , pp. 2895-2908.

7. Emam, M. I. 2008. Studies on infectious canine hepatitis in dogs. M. Vet. Sci. Thesis (Infectious Diseases), Fac. Vet. Med., Zagazig Univ.

8. Greene, C.E. 1990. Infectious canine hepatitis and canine acidophil cell hepatitis. In: Infectious Diseases of the Dog and Cat, $2^{\text {nd }}$ ed., pp. 22-27.

9. Emam; M.I.; Moustafa, A.M.; Hamoda, F.K; Ibrahim, E.M. and Khodeir, M.H. 2013. Effect of some drugs on liver and kidney functions in dogs. Zag. Vet. Med. J. (ISSN.1110-1458) Vol. 41 No.3: 38- 45.

10. Hanan, S. Abd El- Raouf. 1998. Metabolic and endocrine changes associated with active immunization of goats against pest des petits ruminants virus (PPR). PhD. Vet. Thesis,( Physiology), Fac. of Vet. Med., Cairo Univ.

11. Harrach, B.; Benkő, M.G.W.; Both, G.W.; Brown, M; Davison, A. J.; Echavarría, M. and Hess, M. 2011. Virus Taxonomy: Classification and Nomenclature of Viruses. Ninth Report of the International Committee on Taxonomy of Viruses Elsevier, San Diego, pp: 125-141.

12. Kataria, A. K. and Sharma, K. N. 1993. Serum electrophoretic studies in sheep vaccinated with live sheep pox virus (Roumanian strain). Ind. Vet. J., 70 (2): 191-192. 
13. Kelly, W. R. 1993.The liver and biliary system. In: Pathology of domestic animals, ed. Kennedy CK, Jubb KVF, Palmer N, $4^{\text {th }}$ ed., pp. 364-365. Academic Press San Diego, CA.

14. Khodeir, M.H.; Attyat, M. Kotb; Amani, A. Saleh and Daoud, A.M. 2003. Studies on canine hepatitis in Egypt II-Preparation of live attenuated vaccine against canine hepatitis. $3^{\text {rd }}$ Int. Conf. Mansoura, 317-328.

15. Mohammadi, A., Masoudian, M. and Nemat, Y. 2011. Evaluation of PCR techniques for detection and differentiation of canine adenoviruses in fecal samples in Shiraz. Iran. BJVM, 14, (4): 247-251.

16. Mouaz, M. A.; Gehan, K. M.; Khirat, A. Elian; Aida, I. Debagy and Khdeir, M. H. 1998. Evaluation of immune response in Egyptian sheep vaccinated with attenuated RVF and PPR vaccines. Assiut Vet. Med. J., 38 (67): 111-122.

17. Patton, C.J. and Croush, S.R. 1977. Enzymatic colorimetric determination of serum urea. Anal. Chem., 49: 464-469.

18. Reitman, S. and Frankel, S. 1957. A colorimetric method for determination of serum glutamic oxaloacetic transferase and serum glutamic pyruvic transferase. Am. J. Clinc. Path., 28:56.

19. Robert D., J. and Keith, W. P. 1986. Veterinary Laboratory Medicine. $2^{\text {nd }}$ Ed. Iowa State Univ. Press.

20. Sharma, D. P.; Mslik, P. D. and Sapra, K. L. 1973. Age-wise and species-wise haematological studies in farm animals. Ind. J. Anim. Sci., 43 (4): 289-295.

21. Singh, K.V.; Osman, O.A.; Thanaa, I.Baz and Ivon, El-Cicy. 1967. Colostral transfer of rinderpest neutralizing antibodies to offspring of vaccinated dams. Can. J. Comp. Med. Vet. Sci., 31: 295-298.

22. Soliman, M. K.; Abd El.- Rahman, M; Rizkalla, E. H.; Bishara, N. B. and Yanny, A. A. 1996. Effect of pre-lambing vaccination with clostridial vaccine on blood constituents in sheep and their lambs. Egypt. J. Agric. Res., 74 (1): 253-264.

23. Soma, T. 2002. Diagnostic application of immunoperoxidase plaque staining test to antibody testing against canine distemper virus. J. Environ. Dis., 11: 5-12.

24. Taha, S. M.; El-Helo, I.A. and Osman, O.A. 1984. Studies on the effect of tissue culture rinderpest vaccine on the blood picture of buffaloes. Agr. Res. Rev., Vol. 62 (28): 198-208.

25. Twark, L. and Dodds, W. 2000. Clinical use of serum parvovirus and distemper virus antibody titers for determining revaccination strategies in healthy dogs. J. Am Vet. Med. Assoc., 217:1021-1024.

26. Whetstone, C. A.; Draayer, H. and Collins, J.E. 1988. Characterization of canine adenovirus type 1 isolated from American black bears. Am. J. Vet. Res., 49:778780.

27. Yasummra, Y. and Kawatika, Y. 1963. Studies on S.V. 40 virus in tissue culture. Nihon Rhino, 21:1201-1215. 


\section{دراسات مناعية و إكلينيكية على الكلاب المحصنة بلقاح فيروس أدينو الكلاب-1 الحى المستضعف}

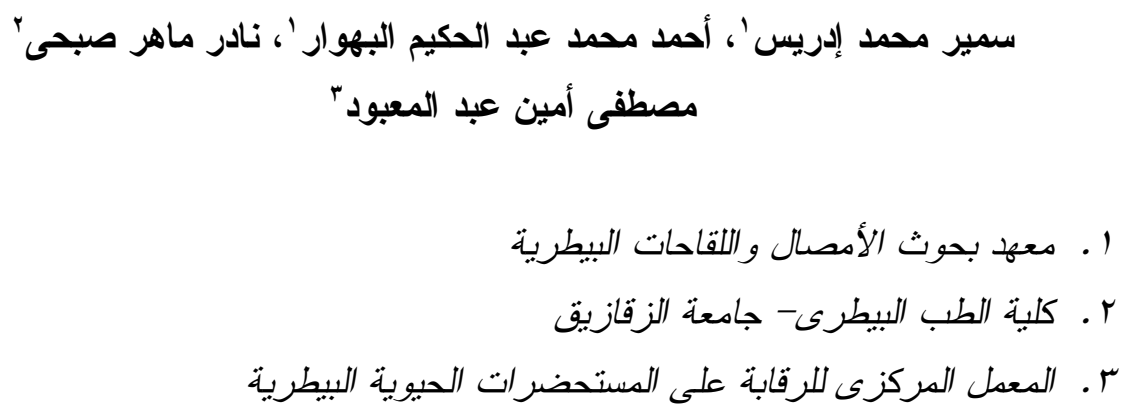

تم خلال هذا العمل دراسة مناعبة و إكلينيكية على الكلاب المحصنة بلقاح الالتهاب الكبدى مئى

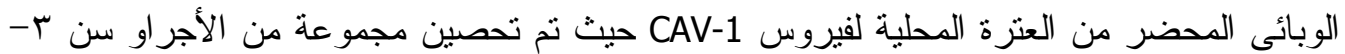

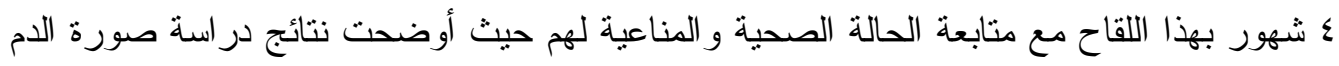

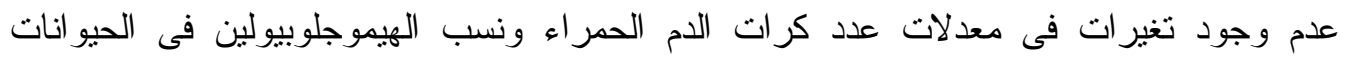

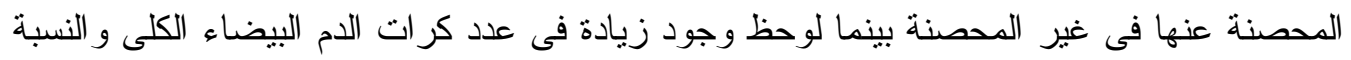

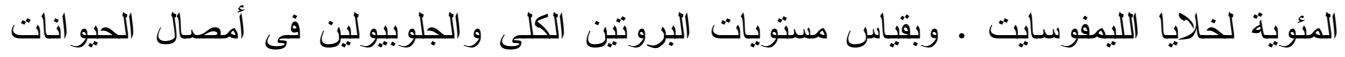

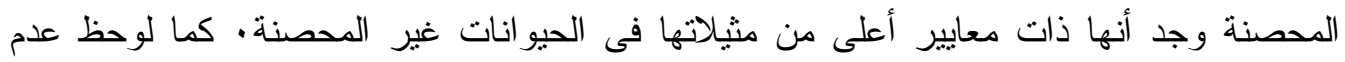

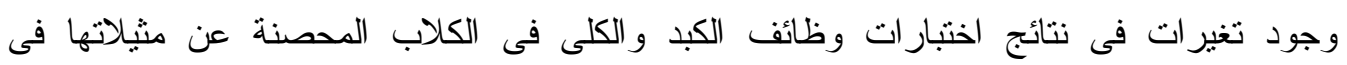

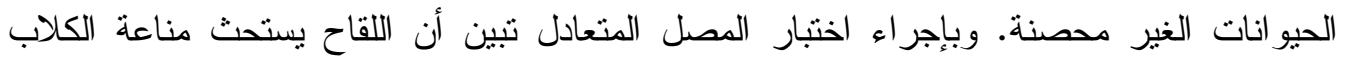

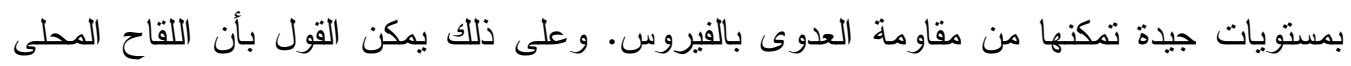

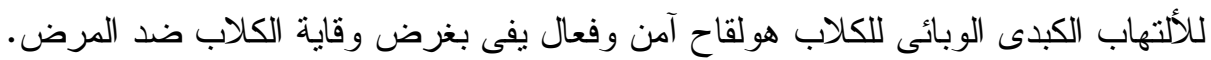

